\title{
NON-NATIVE SPEAKERS' RHETORICAL COMMONALITIES IN WRITING SCRIPT INTRODUCTION SECTION
}

\author{
Iskandar Abdul Samad $^{1}$; Bustami Usman² Novalia Rizkanisa $^{3}$; Siti Sarah Fitriani ${ }^{4}$ \\ 1,2,3,4 English Education Department of Syiah Kuala University, Banda Aceh \\ Jl. Teuku Nyak Arief, Kopelma Darussalam, Banda Aceh 23111, Indonesia \\ 'iskandar.abdul.samad@unsyiah.ac.id; ${ }^{2}$ bustami55@yahoo.com; \\ ${ }^{3}$ novalia.rizkanisa@gmail.com; ${ }^{4}$ ssfitriani@gmail.com
}

Received: 01 ${ }^{\text {st }}$ May 2017/Revised: $28^{\text {th }}$ November 2017/Accepted: $13^{\text {th }}$ December 2017
How to Cite: Samad, I. A., Usman, B., Rizkanisa, N., \& Fitriani, S. S. (2018). Non-native speakers' rhetorical commonalities in writing script introduction section. Lingua Cultura, 12(2), 141-147.
https://doi.org/10.21512/lc.v12i2.2475

\begin{abstract}
This research analyzed the rhetorical pattern (RP) of script Introduction section written by undergraduate students at four selected universities in Aceh. Information about the RP of introduction section had been found in literature, including the work of Indonesian students in general. However, specific information about the RP of the work of EFL students in Aceh was not determined yet. The main aim of the study was to explore whether Acehnese students performed the exact pattern of written Academic English. Understanding the RP of this section was important because it helped readers to have a description of the whole script. A qualitative method was applied in this study to draw the RP through the content analysis. The data were taken from twenty undergraduate students' scripts at four selected universities. CARS model was used to analyze all the data. In general, the result shows a unique RP of the Introduction section by Acehnese students where RP of introduction section maintains the circular way of thinking.
\end{abstract}

Keywords: rhetorical pattern, introduction section, writing script, non-native speakers

\section{INTRODUCTION}

English is considered as a foreign language in many countries, including Indonesia. Learners whose English is not their first language, have tendencies to interfere their target language (English) with the convention of their native language (L1) in their writing. It is inevitable that this kind of fact becomes a challenge to all teachers and students. Many kinds of research have been conducted to examine students' writing whose English is not their first language. One of the focuses is on the rhetorical pattern (RP) of research introduction section.

Swales (1990) who has proposed Creating a Research Space (CARS) model and used it as a tool to analyze the research article. It finds that in the Introduction section, the majority of EFL/ESL journals/articles are influenced by their first language convention. The RP of the writing is different from the convention in L2. The similar finding is also found by Gecikli (2013). In his research, he finds that Turkish students do not fully follow the moves and steps application in CARS model for their Ph.D. dissertation. Sheldon (2011) on his study, also shows considerable variations of English writing from the three groups of writers. Writers whose English is their L1 is clearly good in writing English. Yet, those whose English is their L2 do not display a good resemblance to the English convention. These researchers' findings are evidence that different students have their own way of writing. These variations are influenced by their native language. Therefore, it is convinced that $\mathrm{L} 1$ interferes L2 in the way of writing the academic texts.

Additionally, what has been done by Choe and Hwang (2014) in their research, it finds that even tough Korean students maintain good resemblance with CARS model, but the content is rather a liberal form of the CARS model. A brilliant idea also comes from Wijayanti (2017) who analyzes different corpus but it still with the similar point. She analyzes the job application letter which becomes the introductory part accompanying the resume. Then the result yields that Indonesian as a cultural background lies in the job application letter.

In Indonesia, writing a script is a must for undergraduate students to graduate (Samad \& Adnan, 2016). This script is written in a formal way that sounds academic. The academic writings include script, thesis, and dissertation. In Indonesia, the term used for these academic texts is different according to the level of education. For 
undergraduate, it is called script; the thesis is called for Master's degree, and dissertation is for Doctoral degree (Samad, 2016). Writing the script is essential for university students to complete their studies. Even, students are required to perform orally and defend it to what has been written in the script. If they do not complete it, they can not graduate and receive a bachelor certificate (Samad \& Adnan, 2017). For the purpose of this research, researchers attempt to find out students' RP of their undergraduate script Introduction section at two universities, Islamic and nonIslamic universities in Aceh.

The common issue among students in this country is that students find it difficult to produce appropriate writing for the Introduction section. Swales and Feak (2001) have mentioned that dealing with the introductory part is difficult and quite troublesome for non-native speakers. The introductory part maintains the richness of a research idea. Understanding the rhetorical pattern of writing this section is important because it is considered as a window to the whole script.

Some researchers have provided in the literature the RP of Introduction section (e.g., Hinkel, 2004; Swales \& Feak, 2001). One of the examples of the RP of Introduction section can be seen in the overall shape of a research article in Figure 1.

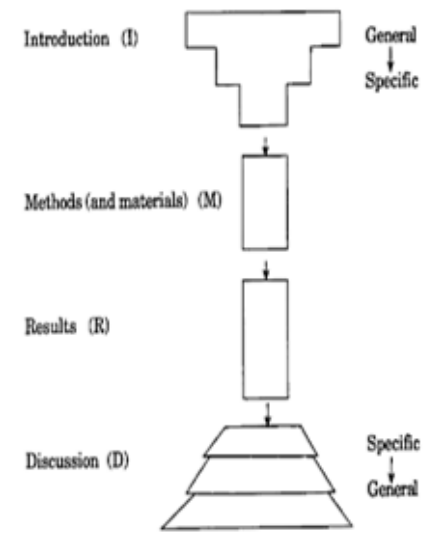

Figure 1 Overall Pattern of Research Article (Swales \& Feak, 2001)

Figure 1 indicates the typical pattern of a research article which consists of Introduction, Methods, Results and Discussion. For this research, the focus is limited to the Introduction section of the script written by EFL students in Aceh. This section is important because it attracts the reader's attention. As stated by Swales and Feak (2001) that the introduction section provides the rationale for the paper, moving from general discussion of the topic to the particular question or hypothesis being investigated. The students are required to locate their research ideas into paragraphs to give the clear direction of what the writers are going to find out. The Introduction section provides relevant idea related to the topic in the research so that readers understand.

Creating a Research Space (CARS) is a common model used by researchers to analyze RP of research article Introduction. This model is pioneered by Swales (1990) that provides a series of analytical units in terms of moves and steps. There are three moves in CARS Model. Move 1 is establishing a territory with three steps. Step 1 is claiming centrality, Step 2 is making the topic generalization, and Step 3 is reviewing items of previous research. Move 2 is establishing a niche with Step 1 is counter-claiming, Step 2 is indicating the gap, Step 3 is the question - raising, and Step 4 is continuing the tradition. Move 3 is occupying a Niche with Step 1 is outlining the purpose, Step 2 is announcing present research, Step 3 is announcing principal findings, and step 4 is indicating the structure of research article.

After the previous version, Swales (2001) has proposed a new version with three moves. Move 1 is establishing a research territory. It can be done by; (a) showing that the general research area is important, central, interesting, problematic, or relevant in some way. (optional), (b) introducing and reviewing items of previous research in the area (obligatory). Move 2 is establishing a Niche that can be done by indicating a gap in the previous research, raising a question about it, or extending previous knowledge in some way (obligatory). Move 3 is occupying a Niche. It can be done by; (a) outlining purposes or stating the nature of the present research (obligatory), (b) announcing principal findings (optional), (c) indicating the structure of Research Paper (optional).

The Swales' model above has several moves and steps. This revised CARS model in 2001 seems easy to understand. The term obligatory and optional are used in each move.

Swales keeps revising the model in which in 2005 that he completed another model. This model is the latest model. The researchers use this model as an analytical tool for this research. The details of moves and steps can be seen in Figure 2.

\author{
Move 1: Establishing a territory (citations required)

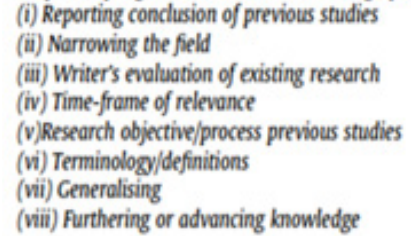

Figure 2 Moves and Steps

in Research Article Introduction (Swales, 2005)

Many researchers have used this latest CARS model. Sheldon (2011) uses the model in Figure 2 to examine the rhetorical differences in Introduction of the research article by English L1, L2, and Castilian Spanish L1. Suryani et al. (2014) also use that model toward English written text by Malaysian. Then, Khamkhien (2015) also conducts the research by using this model toward Thai journal.

As aforementioned, this present study attempts to draw the RP of Introduction section of English undergraduate script that is written by Acehnese students with the standardized rhetorical pattern of the Introduction 
section. This finding could be considered as the initial stage prior to giving any treatment for participants to be able to write appropriate Introduction section which is suitable for international readers. This research contributes to two benefits; practically, this article could help lecturers to teach their students. Secondly, this article could contribute to the body of knowledge by filling the gap in the literature regarding the RP of Introduction section written by Acehnese EFL students in four universities/institutes in Aceh, Indonesia. The combination of Islamic and non-Islamic universities is still rare to be presented. Therefore, the result of this research could contribute significant benefits to both practical and knowledge significance.

\section{METHODS}

This research is conducted by using a qualitative study that is investigating the RP of Introduction section of the scripts written by the Acehnese students. The qualitative research focuses on the research of social phenomena on giving and obtaining culturally specific information to the feelings and perceptions of the participants under research (Lodico, Spaulding, \& Voegtle, 2006). The content analysis is used in this study, which attempts to analyze the rhetoric reflected in students' Introduction section (Schreiber \& Asner-Self, 2011). The corpus data are required to deal with the number of English undergraduate scripts written by Acehnese students. The researchers collect 20 undergraduate scripts of English Education Department students from four selected universities/institutes in Aceh. Two universities are Islamic universities (IAIN Zawiyah
Cotkala Langsa and UIN Ar-Raniry) and the other two are non-Islamic universities (Samudra Langsa University and Syiah Kuala University). The data are acquired from each university library and official digital library.

The researchers analyze the whole part of Introduction section using Creating a Research Space (CARS) model proposed by Swales (2005). It is scrutinized to discover the rhetorical pattern in the Introduction section based on Swales' framework. As stated by Sheldon (2011) that a move describes patterns of organizational content, which carry a particular role in the overall goals of the Research Introduction.

\section{RESULTS AND DISCUSSIONS}

The Introduction section is considered to be the most complicated part for some writers, especially for EFL writers. By adapting the CARS model by Swales (2005), this research analyzes the rhetorical pattern reflected in the Introduction section of twenty Acehnese undergraduate students' scripts. Then, the analysis is done by utilizing the CARS model by Swales which proposes three moves. The whole part of the Introduction section is analyzed in this analysis.

The researchers analyze the whole parts of Introduction section by using CARS model. Then, the data are gathered from the move analyses which then are tabulated in Table 1. UGS is Undergraduate Script. Move 1 contains one step and eight sub-steps. Move 2 contains three steps. And Move 3 contains seven steps.

Table 1 Moves Occurrences in English Undergraduates Thesis Introduction

\begin{tabular}{|c|c|c|c|c|c|}
\hline \multirow[t]{2}{*}{ Number of Scripts } & \multicolumn{3}{|c|}{ MOVES } & \multirow[t]{2}{*}{ Move Cycle } & \multirow[t]{2}{*}{ Number of Paragraph } \\
\hline & MOVE 1 & MOVE 2 & MOVE 3 & & \\
\hline UGS 1 & 6 & 2 & 5 & 12123 & 12 \\
\hline UGS 2 & 7 & 2 & 5 & 121213 & 18 \\
\hline UGS 3 & 7 & 2 & 5 & 121213 & 10 \\
\hline UGS 4 & 8 & 2 & 5 & 121213 & 15 \\
\hline UGS 5 & 7 & 2 & 5 & 12123 & 7 \\
\hline UGS 6 & 8 & 1 & 5 & 1213 & 6 \\
\hline UGS 7 & 5 & 2 & 5 & 1213 & 10 \\
\hline UGS 8 & 4 & 2 & 5 & 1213 & 6 \\
\hline UGS 9 & 2 & 2 & 4 & 123 & 6 \\
\hline UGS 10 & 5 & 2 & 5 & 12123 & 6 \\
\hline UGS 11 & 5 & 2 & 6 & 121213 & 11 \\
\hline UGS 12 & 4 & 2 & 5 & 12123 & 5 \\
\hline UGS 13 & 5 & 2 & 6 & 1213 & 11 \\
\hline UGS14 & 6 & 2 & 6 & 121213 & 14 \\
\hline UGS 15 & 6 & 1 & 6 & 1213 & 8 \\
\hline UGS 16 & 5 & 1 & 4 & 123 & 11 \\
\hline UGS 17 & 6 & 2 & 5 & 12123 & 13 \\
\hline UGS 18 & 6 & 2 & 5 & 12123 & 10 \\
\hline UGS 19 & 6 & 2 & 5 & 12123 & 11 \\
\hline UGS 20 & 4 & 2 & 5 & 12123 & 11 \\
\hline
\end{tabular}


Based on Table1, it can be seen that 20 scripts of Introduction have considerable variations of moves. The number in the column Move 1-3 is referring to items of each section in Figure2, which is used as an analytical tool for this research. Besides, the move cycle shows how the students create their rhetorical pattern that becomes their preference in their writing. Most of the written texts have similar move cycles in the Introduction section. Furthermore, as revealed by Gecikli (2013), the length of introduction results in a change in the number of moves. The longer the length of introduction is, the higher frequencies of moves are.

Above all, the researchers carry out closer scrutiny of each of the three moves. Notably, all undergraduate scripts contain the three main moves which are considered as complete. The steps and the sub-steps in each move in the theses are discussed in more detail. Table 2 is the description of the first move. Move 1 is establishing a territory (citation required).

Table 2 Detailed Occurrences of Move 1 in Introduction Section

\begin{tabular}{clc}
\hline & \multicolumn{1}{c}{ Structure of Move 1 } & $\begin{array}{c}\text { Number } \\
\text { of scripts }\end{array}$ \\
\hline Step 1 & $\begin{array}{l}\text { Topic generalization of increasing } \\
\text { specificity }\end{array}$ & 20 \\
(i) & $\begin{array}{l}\text { Reporting conclusion of previous } \\
\text { studies }\end{array}$ & 10 \\
(ii) & Narrowing the field & 20 \\
(iii) & Writer's evaluation of existing & 14 \\
(iv) & Time-frame of relevance & 20 \\
(v) & Research objective/process of previ- & 13 \\
(vi) & Teus studies & 20 \\
(vii) & Generalizing & 6 \\
(viii) & Furthering or Advancing knowledge & 0 \\
\hline
\end{tabular}

From Table 2, it can be seen that Step 1 of Move 1 which informs readers that the basic field of their research is surely employed by all Acehnese students. The following text illustrates Step 1. UGS 1 is "Reading is one of the four language skills taught and learned at school and university. Through reading, the students can develop another language skill such as writing". The sub-step (i) is "Reporting conclusions of previous studies" was used only in 11 scripts which are illustrated:

UGS 2 (i) Based on previous research on teaching speaking, it was found that the general problem faced by students in speaking skill is the student cannot speak English actively.

The finding of previous studies can reflect the richness of the current literature, but there are only ten scripts that put sub-step (i). The rest of the scripts locate too much general knowledge in this part or making the general statement toward the study.

Then, the sub-step (ii) "Narrowing the field" is an obligatory in Acehnese undergraduate scripts. It is firmly shaped, for example, in the Introduction section written by UGS 8:
UGS 8 (ii) This thesis talks about bitter experiences. Bitter experience is the great unhappiness or sad event in person's life.

The corpus texts of UGS 8 imply the scope of the research area that is proposed by the students to narrow their present research. Yet, the term narrowing the field does not solely indicate the placement of the thesis.

The next sub-step is (iii) "Writer's evaluation of existing research" with only 14 scripts using it. One of the examples is written by UGS 14 .

UGS 14 (iii) Some writers define a difficult text according to the sentence-length. The text with the longer sentence and longer words are more difficult to understand.

Having the current literature can increase the certainty of the research. Similarly, sub-step (iv), "Timeframe of relevance" presents the supporting disciplines in the research where citations are required in this sub-step.

UGS 5 (iv) It is important to help the students reduce their errors. We need to know the source of error to overcome the problem. Scholar mentions two main sources of errors, namely inter-lingual and intra-lingual. Inter-lingual refers to the interference of learner's mother tongue to the target language. Then, intra-lingual refers to the students' lack of knowledge of target language.

The firm sub-step (vi) in the Introduction section reflects that the Acehnese students are aware of the importance of research literature in their scripts and this part absolutely needs to include the citation. Besides, this substep can give readers the background information needed to understand the research. Last but not least, the following sub-step (vii) has a lower number of occurrences in the Introduction section of the Acehnese undergraduate scripts.

UGS 11 (vii) The important thing of the test analysis is first, to improve the quality of the test itself and the second is to assess and examine each test item in order to obtain qualified test before use and reuse.

The lower number of occurrences of sub-step (vii) is due to the unfamiliarity of the Acehnese students in generalizing the whole part in their scripts. The last one is sub-step (viii) "Advancing knowledge". Unfortunately, the last sub-step is totally absent in the Acehnese Introduction section. From the analysis of step and sub-steps of Move 1, the researchers find the sub-steps included in Move 1 are not ordered sequentially in their scripts

Move 2 is establishing the Niche (Citation Possible). This second move presents the research through the description of the problem and giving a detailed limitation of the research. As it can be seen in Table 3, the occurrences of move 2 have a larger number.

Eventually, some of the corpus scripts use the citation to support the research. Specifically, Step 1 A has the greatest occurrences in move 2 which is illustrated in the example. 
Table 3 Detailed Occurrences of Move 2 in Introduction Section

\begin{tabular}{clc}
\hline \multicolumn{2}{c}{ Structure of Move 2 } & $\begin{array}{c}\text { Number } \\
\text { of scripts }\end{array}$ \\
\hline Step 1 A (S1A) & Indicating a Gap & 20 \\
Step 1 B (S1B) & $\begin{array}{l}\text { Adding to what is } \\
\text { known }\end{array}$ & 17 \\
Step 2 & $\begin{array}{l}\text { Presenting positive justi- } \\
\text { fication (optional) }\end{array}$ & 0 \\
\hline
\end{tabular}

UGS 6 (S1A) Even though reading has been taught from elementary school, it cannot be sure that all students in junior high school level can understand the reading text well.

Based on the illustration, it can be seen that the Acehnese students try to highlight problematic issues in their research and give critical comments addressing the gap. This step also works as a justification strategy in leading them to the necessity of conducting the research question.

On the contrary, step 1B is only included in 17 scripts. This number shows the Acehnese students are able to reinforce the information already known to relate to the research question. The example can be seen in UGS 5 .

UGS 5 (S1B) Some scholars have same ideas that how error analysis can be used to provide the information for teachers about the errors made by students in their speaking. It might help the teachers to reduce students' error in speaking performance.

The next step is Step 2, "Presenting positive justification". As stated in Swales' model, Step 2 is clearly optional. From the analysis, the use of Step 2 in the twenty scripts of Acehnese students is absolutely absence.

Based on the description of Move 2, it is found that the Acehnese students have enough awareness of establishing the niche in their research by writing Step $1 \mathrm{~A} / 1 \mathrm{~B}$. Even though, it is undeniable that they still reflect their unfamiliarity with English writing convention.

The final move is "Presenting the present work" or Move 3 with possible use of citation. As revealed by Swales (2005), Move 3 is served by outlining the research purpose, stating its structure and main features, and announcing the principal outcomes. The detailed description of Move 3 can be seen in Table 4.

Table 4 Detailed Occurrences of Move 3 in Introduction Section

\begin{tabular}{clc}
\hline \multicolumn{2}{c}{ Structure of Move 3 } & $\begin{array}{c}\text { Number } \\
\text { of scripts }\end{array}$ \\
\hline Step 1 (S1) & $\begin{array}{l}\text { Announcing present } \\
\text { work descriptively and/ } \\
\text { or purposively (obliga- } \\
\text { tory) }\end{array}$ & 20 \\
Step 2 (S2) & $\begin{array}{l}\text { Presenting research } \\
\text { questions or hypothesis } \\
\text { (optional) }\end{array}$ & 20 \\
Step 3 (S3) & $\begin{array}{l}\text { Definitional clarifica- } \\
\text { tions (optional) }\end{array}$ & 20 \\
\hline
\end{tabular}

Table 4 Detailed Occurrences of Move 3 in Introduction Section (continued)

\begin{tabular}{clc}
\hline \multicolumn{1}{c}{ Structure of Move 3 } & $\begin{array}{c}\text { Number } \\
\text { of scripts } \\
\text { Step 4 (S4) }\end{array}$ & $\begin{array}{l}\text { Summarizing method } \\
\text { (optional) }\end{array}$ \\
Step 5 (S5) & $\begin{array}{l}\text { Announcing principal } \\
\text { outcomes (PISF)* }\end{array}$ & 2 \\
Step 6 (S6) & $\begin{array}{l}\text { Stating the value of the } \\
\text { present paper (PISF)* } \\
\text { Outlining the structure } \\
\text { of the paper (PISF)* }\end{array}$ & 9 \\
\hline
\end{tabular}

*PISF: Probably in Some Fields

By verifying the corpus data, the researchers find that all of the Acehnese scripts in this research write Step 1, "Announcing present work descriptively and/or purposively" in the last paragraph of the research background part, which is also in the Introduction section. The example is shown in UGS 7.

UGS 7 (S1) It is really expected for the teacher to employ the STAD method in making the good achievement for the students to write the descriptive writing. Based on the explanation, the writer interested in conducting a research entitled "The using STAD method in improving students writing descriptive paragraph to the tenth grade students of MAS Ulumul Qur'an Langsa".

The above example shows that the Acehnese students truly make claims of the research. The next step is step 2, "Presenting research question or hypothesis" which is illustrated in UGS 17.

UGS 17 (S2) Based on the explanation, the problem of the study is: does collaborative learning improve reading skill to the class of SMPN 1 Karang Baru?

All Acehnese students in this research write this step in their scripts to give a precise description of what their research is trying to find or measure. The further step is step 3, "Definitional clarifications". Although Swales highlights this step as optional, all Acehnese students include this step in their script. For example:

UGS 10 (S3) As one said, moral value is simply an important kind of instrumental value. Actions and traits of character have moral value insofar as they contribute in certain way of to happiness: to enhance pleasure or reduce pain or both.

Step 3 in the Introduction is used to inform readers of how specific concepts are understood in each study. Moreover, the aim of this step is to situate the research in a specific area that needs attention. This step has a good portion of the Acehnese scripts analyzed for this research.

Only half of the scripts involved in this research include Step 4 "Summarizing methods". The choice of step 4 is based on the standard of writing procedure in each university. One of the examples is: 
UGS 16 (S4) The correlation study is used in this study to see the correlation between reading comprehension and writing ability to the eleventh grade students of SMKN 4 Langsa.

From the example, it can be seen that the research methodology is firmly elaborated and outlined to show readers the methodology used in the research.

The next one is step 5 "Announcing the principal outcomes". This step has a lower number of occurrences. Only two scripts represent this step as in the following example:

UGS 15 (S5) Facebook group also allowed for most immediate feedback and fun interaction that the writer hopes will motivate students to write. I can claim that Facebook group will benefit the students in motivating them to write autonomously.

The Acehnese students obviously seem to restrain in announcing the main findings of their studies. The examples above are not fully good examples of step 5, but the tendencies of the text imply the announcing of the principal outcome.

Step 6 "Stating the value of the present research" is similar to the scope of the study written in students' scripts.

UGS 10 (S6) From all the books, the writer just take one book entitled "The Aesop for Children; with Pictures by Wilo Winter. The writer chose this book because the language in this book is simpler than other books and each story ending has a conclusion or moral value.

There are only nine scripts that include Step 6 in the Introduction while this step is absence from the other 11 scripts. Those who do not include Step 6 in their script think that they have presented their research in Step 1, where they make strong claims for the validity of their research.

The last one is Step 7 "Outlining the structure of the paper". As stated in the CARS model, Step 7 is in the term of PISF which stands for 'Probably in Some Fields'. From the analysis that researchers did to the students' scripts, none of them wrote Step 7. Particularly, the Acehnese students of this research have no obligation to announce the structure of their paper.

As a matter of fact, the researchers find that the Acehnese students in this research realize the use of move 3 using Step 1, 2, and 3. However, Step 4, 5, and 6 are used less in their scripts. The cyclical pattern of CARS move is considered essential to see how Acehnese students elaborate their research idea in the Introduction section.

Undoubtedly, paying attention to the cyclical pattern of moves is also of paramount importance. The previous table has already shown the cyclical pattern of moves. Table 1 shows that 12 scripts display similar move cycles in the moves formula of 1-2-1-2. Then, the rest of the scripts display the formula $1-2-1-3,1-2-3,1,2,2,3$. From these move cycles, it can be concluded that Acehnese students tend to put the foundation of their research territory first by providing the background. Although the idea is a little unorganized, they still tend to establish the niche and present their studies firmly in the last move or Move 3.
Additionally, as it is argued by Swales (2005), the length of introduction may affect the shape of the cycle moves. Due to this reason, a longer introduction has a greater probability of cycling. As mentioned, it can be proven that the numbers of paragraphs in the Introduction section of students' scripts influence its move cycling.

Twenty undergraduate scripts in this research accomplish all the three moves, namely Move 1 (Establishing the territory), Move 2 (Establishing the niche), and Move 3 (Presenting the present work). Based on the scripts, the Acehnese students also completely carry out the obligatory part of each move, such as establishing territory with citation required, indicating a gap and announcing the present research. Notably, according to Swales (2005), the use of Step 2 "presenting research question" and Step 3 "definitional clarifications" in Move 3 is optional. On the contrary, both steps seem to be an obligatory step in the Acehnese undergraduate scripts. Indeed, it can be proven that the Acehnese students used both steps in their Introduction section. It is also supported by Chahal (2014) in his research that Move 1 achieves primarily in the Introduction. The students lay the information on the research discussed. Conversely, none of them write the "Furthering/advancing knowledge", "presenting positive justification" and "outlining the structure of the paper" in the script. Due to their unfamiliarity with those parts, they never use those steps/substeps. This unfamiliarity could be influenced by the students' first language as it is also found in the work of Gecikli (2013) and Sheldon (2011).

Based on the cyclical pattern of moves, it can be seen that most of the cyclical patterns are in the formula 1-21-2-3. The formula shows that Move 1 and Move 2 recur in the Acehnese scripts. The recurring patterns to justify the identification of gap seem to be a dominant way that helps the students build the gap in their research. Hence, the Acehnese students tend to apply a circular way in the introduction of the script. This result is also found in Huda (2016) in which the students apply the circular way in presenting their introductory part. They start the introduction by explaining the general area of their research. Then, narrowing the research is in the middle of introduction, or it is placed at the end of the text. Even though most of the Acehnese students have applied the rhetorical pattern as suggested by Swales, however, the arrangement of the move and steps remains disordered. Again, this is evidence that students' first language interferes the way of writing in their target language.

\section{CONCLUSIONS}

Most Acehnese students write the Introduction section for their scripts have fulfilled CARS model as it is proposed by Swales (1990). However, the order of steps is not exactly the same as in the CARS model. There is slightly difference between CARS model and the rhetorical pattern used by the Acehnese students. Since the basic language is the difference, then the remarkable distinction of written academic English exist.

This result becomes a unique and could extend the information of types of rhetoric in script writing. Lecturers and students could teach students rhetorical pattern of the script as it is highly required to make readers convinced with the information delivered in the script. 


\section{REFERENCES}

Chahal, D. (2014). Research article Introductions in cultural studies: A genre analysis explorations of rhetorical structure. Journal of Teaching English for Specific and Academic Purposes, 2(1), 1-20.

Choe, H., \& Hwang, B. H. (2014). A genre analysis of Introductions in theses, dissertations and research articles based on Swales' CARS Model. Korean Journal of Applied Linguistic, 30(1), 3-31.

Gecikli, M. (2013). A genre-analysis study on the rhetorical organization of English and Turkish PhD theses in the field of English language teaching. International Journal of Business, Humanities, and Technology, 3 (6), 50-58.

Hinkel, E. (2004). Teaching academic ESL writing. New Jersey: Lawrence Erlbaum Associates.

Huda, T. (2016). Reflection of rhetorical pattern in the Introduction of academic research reports. Proceeding of International Conference on Teacher Training and Education, 1(1), 657-662.

Khamkhien, A. (2015). Textual organisation and linguistic features in applied linguistics research articles: Moving from Introduction to Methods. International E-Journal of Advances in Social Sciences, 1(2), 111120.

Lodico, M., Spaulding, D., \& Voegtle, K. H. (2006). Method in educational research. San Fransisco: Jossey-Bass.

Samad, I. A. (2016). Improving students' competence in the thesis defence examination in two universities in Aceh, Indonesia. Unpublished Doctoral Dissertation. Armidale: University of New England.
Samad, I. A., \& Adnan, Z. (2016). Generic structure of an important, but neglected, academic genre, thesis event examination, and its pedagogic implications. Proceeding of TESOL Indonesia International Conference Edition, University of Mataram. Lombok: ELE Publishing.

Samad, I. A., \& Adnan, Z. (2017). Using a genre-based approach to prepare undergraduate students for an English thesis defence examination: An experimental study to address the Pedagogical Controversy'. Linguistik Indonesia Journal, 35(1), 75-93.

Schreiber, J., \& Asner-Self, K. (2011). Educational research. New Jersey: JohnWiley \& Sons.

Sheldon, E. (2011). Rhetorical differences in RA Introductions written by English L1 and L2 and Castilian Spanish L1 writer. Journal of English Academic Purposes, 10, 238-251.

Suryani, I., Kamaruddin, H., Hashima, N., Yaacob, A., Rashid, S. A., \& Desa, H. (2014). Rhetorical structure in academic research writing by non-native writers. International Journal of Higher Education, 3(1), 29-38.

Swales, J. M. (1990). Genre analysis. Cambridge: Cambridge University Press.

Swales, J. M., \& Feak, C. B. (2001). Academic writing for graduate students: Essential task and skill. Ann Arbor: University of Michigan.

Swales, J. M. (2005). Research genre; Exploration and application. New York: Cambridge University Press.

Wijayanti, S. H. (2017). The moves of Indonesian application letters. Lingua Cultura, 11(1), 39-45. 